\title{
Modal Utama Agar Menjadi Guru Favorit Bagi Peserta Didiknya
}

\author{
Yazidul Busthomi \\ Dosen Institut Agama Islam Al-Qolam Gondanglegi Malang, Indonesia \\ Email: yazidulbusthomi03@gmail.com
}

\begin{abstract}
Being a teacher is a truly noble job. He is responsible not only to make the intelligent human beings in the field of science, but also good moral in this life. A human child who at first did not understand anything, in the presence of a teacher educated to understand life better and get to know the world. On the shoulders there are tasks and responsibilities for the future of a smarter and more intelligent generation. So noble work of a teacher as well as how heavy the duties and responsibilities of being a teacher. This is why not everyone can be a successful teacher. Only certain people who have a sense of love for children or learners and dedicated to the world of education are able to become a teacher. This is the person of a teacher who successfully teaches and educates in front of his students, the figure of a favorite teacher loved by his protege. The main capital to be a favorite teacher for students that is as follows: 1. Close to students, 2. Build a fun atmosphere, 3. Can play as a second parent, 4. Become a friend in learning, 5. Personality worth imitating, 6. Be affectionate, 7. Patience in teaching, 8. Not arrogant.
\end{abstract}

Keywords: Teachers, Favorites, Learners 
Dalam dunia pendidikan tidak hanya keluarga yang merupakan faktor utama pendidikan terhadap anak, akan tetapi guru di lembaga sekolah sangat diutamakan dalam mendidik anak didiknya. Guru sebagai subyek yang melaksanakan pendidikan, karena guru mempunyai peranan penting untuk berlangsungnya pendidikan, baik atau tidaknya guru berpengaruh besar terhadap hasil pendidikan bagi peserta didik yang merupakan obyek terpenting dalam pendidikan. Hal ini disebabkan perbuatan atau tindakan mendidik itu diadakan atau dilakukan hanyalah untuk membawa peserta didik kepada tujuan pendidikan yang dicita-citakan.

Anak adalah amanah Allah dan harus dijaga dan dididik untuk mencapai keutamaan dalam hidup dan mendekatkan diri kepada Allah, kedua orang tuanyalah yang akan mengukir dan membentuknya menjadi mutiara yang berkualitas tinggi dan disenangi semua orang karena semua bayi yang dilahirkan kedunia ini, bagaikan sebuah mutiara yang belum diukur dan belum berbentuk tapi amat bernilai tinggi. Maka ketergantungan anak kepada pendidiknya termasuk kepada kedua orang tuanya, tampak sekali.

Usia dini pada kebanyakan manusia memiliki rangsangan dan daya tangkap yang sangat peka terhadap pendidikan. Pendidikan yang harus dialami dan dilakukan oleh manusia adalah pendidikan yang berlangsung seumur hidup, dengan kata lain pendidikan tidak hanya pada usia dini. Maka proses belajar itu bagi seseorang dapat terus berlangsung dan tidak terbatas pada dunia sekolah saja. Esensi pendidikan agama Islam terletak pada kemampuannya untuk mengembangkan potensi anak agar menjadi manusia yang beriman dan bertakwa dan dapat tampil sebagai khalifatullah $f i$ al-ardh. Esensi ini menjadi acuan terhadap metode pembelajaran untuk mencapai tujuan yang maksimal (Ismail, 2009, p.3)

Pendidikan adalah suatu aktivitas untuk mengembangkan seluruh aspek kepribadian manusia yang berjalan seumur hidup (Zuhairini, 2005, p.149). Pendidikan pada hakikatnya adalah pengembangan potensi atau kemampuan manusia secara menyeluruh yang pelaksanaannya dilakukan dengan cara mengajarkan pelbagai pengetahuan dan kecakapan yang dibutuhkan oleh manusia itu sendiri (Muhibbin Syah, 2008, p.35). Pendidikan adalah bimbingan atau pimpinan secara sadar oleh pendidik terhadap perkembangan jasmani dan rohani anak didik menuju terbentuknya kepribadian yang utama (Ahmad Tafsir, 2014, p.24).

Definisi di atas telah menunjukkan bahwa pendidikan adalah suatu cara untuk mendidik seorang agar mencapai tujuan tertentu dalam pendidikan itu sendiri. Begitu juga dengan pendidikan menurut Islam yaitu bimbingan yang diberikan kepada orang lain agar berkembang sesuai dengan dasardasar ajaran Islam. Sebab dalam pendidikan Islam terkandung arahan yang menunjukkan terhadap perbaikan sikap mental dan tingkah laku yang sesuai dengan ajaran Islam baik itu untuk diri sendiri maupun orang lain. Dari sini dapat dijelaskan bahwa pendidikan dalam Islam ialah bimbingan seorang pendidik terhadap anak didik sesuai dengan ajaran Islam agar menjadi seorang muslim yang seutuhnya. 
Dalam dunia pendidikan guru sebagai pendidik harus berakhlakul karimah, karena pendidik adalah seorang penasehat bagi anak didiknya. Dengan berakhlak mulia, dalam keadaan bagaimanapun pendidik harus memiliki rasa percaya diri, istiqomah dan tidak tergoyahkan. Kepribadian pendidik yang dilandasi dengan akhlak mulia tentu saja tidak tumbuh dengan sendirinya, tetapi memerlukan usaha sungguh-sungguh, kerja keras, tanpa mengenal lelah dan dengan niat ibadah. Untuk menjadi teladan bagi anak didiknya, tentu saja pribadi dan apa yang dilakukan oleh seorang pendidik akan mendapat sorotan dari anak didiknya serta orang di sekitar lingkungannya yang menganggap atau mengakuinya sebagai pendidik.

Tugas dan tanggung jawab seorang guru sesungguhnya sangat berat. Di pundaknyalah tujuan pendidikan secara umum dapat tercapai atau tidak. Mengapa di pundak seorang guru dan bagaimana dengan tugas dan tanggung jawab orangtua anak didik yang mendapatkan amanat langsung dari Allah? Pertanyaan penting ini harus dijawab terlebih dulu sebelum membahas persoalan ini lebih jauh. Orangtua memang mendapat amanat/tugas langsung dari Allah untuk mendidik anak-anaknya. Di hadapan Allah kelak para orangtua juga akan dimintai pertanggungjawaban tentang cara mereka mendidik anak-anaknya. Namun, karena kemampuan, pengetahuan, dan waktu yang dimiliki oleh orangtua terbatas, sebagian besar orangtua memercayakan pendidikan anakanaknya kepada guru-gurunya di sekolah.
Tugas dan tanggungjawab seorang guru di sekolah/madrasah semakin berat karena tidak sedikit dari orangtua yang seakan mempercayakan sepenuhnya pendidikan anak-anaknya di sekolah. Mereka beranggapan bahwa tugas dan tanggung jawab orangtua adalah bekerja dan bekerja sehingga mempunyai uang yang banyak untuk memenuhi kebutuhan anak-anaknya, termasuk biaya sekolah. Bahkan, tidak sedikit orangtua yang berusaha dengan sekuat tenaga agar anakanaknya dapat sekolah di tempat yang favorit meskipun biayanya mahal. Orangtua yang demikian biasanya telah merasa bahwa tugas dan tanggung jawabnya di bidang pendidikan anak-anaknya telah selesai. Mereka percaya sepenuhnya bahwa pihak sekolah telah mendidiknya dengan baik sehingga merasa tidak perlu lagi mengontrol pendidikan anaknya ketika di rumah. Sungguh, anggapan yang seperti itu tidaklah benar. Orangtua tetap bertanggung jawab terhadap pendidikan anak-anaknya secara keseluruhan. Sedangkan, guru bertanggung jawab karena mendapatkan amanat dari orangtua untuk mendidik anak-anak mereka, di samping merupakan tanggung jawab kemanusiaan (Akhmad Muhaimin Azzet, 2011, p.18).

Disinilah sesungguhnya tugas dan tanggung jawab guru menjadi tidak main-main. Amanat dari orang tua untuk mendidik anak-anaknya mesti ditunaikan dengan sangat baik. Guru tidak sekedar mengajar, tetapi juga mendidik anak didiknya. Dengan demikian, seorang guru bisa dikatakan sebagai orang tua kedua bagi anak didiknya. Sebagai orangtua kedua, sudah tentu dibutuhkan kedekatan dengan anak didiknya 
agar berhasil dalam menjalankan tugas penting dan mulia ini.

Kedekatan dengan anak didik adalah kunci penting bagi seorang guru bila ingin sukses dalam menjalankan tugas dan tanggung jawabnya. Tanpa kedekatan, tugas dan tanggung jawab itu akan sulit dapat terlaksana dengan baik karena anak didik bukanlah robot yang siap menerima program apa pun dari orang yang membuat atau mengoperasikannya. Anak didik adalah pribadi yang mempunyai jiwa. Sudah tentu, menghadapi pribadi yang mempunyai jiwa dibutuhkan kedekatan di antara dua jiwa agar komunikasi dalam proses pembelajaran dapat berjalan dengan baik.

Menjadi guru adalah pekerjaan yang sungguh mulia. Ia bertanggung jawab tidak hanya menjadikan para anak manusia pandai di bidang ilmu pengetahuan, tetapi juga bermoral baik dalam kehidupan ini. Seorang anak manusia yang pada mulanya tidak mengerti apa-apa, di hadapan seorang guru dididik untuk memahami kehidupan secara lebih baik dan mengenal dunia. Di pundaknyalah ada tugas dan tanggung jawab keberlangsungan masa depan generasi yang lebih cerdas dan berperadapan (Akhmad Muhaimin Azzet, 2011, p.13).

Begitu mulia pekerjaan seorang guru sekaligus betapa berat tugas dan tanggung jawab menjadi seorang guru. Inilah mengapa tidak semua orang bisa menjadi seorang guru yang berhasil. Hanya orangorang tertentu yang mempunyai rasa cinta terhadap anak-anak atau peserta didik dan berdedikasi tinggi terhadap dunia pendidikan saja yang mampu menjadi seorang guru. Inilah pribadi seorang guru yang berhasil mengajar sekaligus mendidik di hadapan murid-muridnya, sosok seorang guru favorit yang dicintai oleh anak didiknya.

Motivasi dan kecintaan seseorang untuk menjadi guru adalah dasar bagi seorang guru akan sukses dan dicintai oleh murid-muridnya atau tidak. Motivasi dan kecintaan ini harus terpancang sejak awal seseorang menekuni profesi sebagai guru atau bisa pula baru terbangunkan setelah seseorang menjalani profesi ini sekian waktu. Motivasi dan kecintaan ini harus senantiasa dijaga agar seorang tetap bersemangat menghadapi anak didiknya dalam proses pembelajaran. Jadi, motivasi dan kecintaan ini semacam ruh bagi seorang guru agar selalu dekat dengan anak didiknya sehingga apa yang disampaikan dalam pembelajaran mudah diterima. Inilah kunci penting bagi keberhasilan seorang guru dalam menjalankan tugas dan tanggung jawabnya. Seorang guru yang tidak hanya mencintai profesinya, tetapi juga dicintai oleh anak didiknya.

Menjadi guru yang mencintai profesi dan dicintai oleh anak didik betapa membahagiakan hati. Sebaliknya, menjadi guru yang sekadar sebagai profesi, biasanya juga akan sekadar dikenal saja oleh anak didiknya secara pribadi. Dalam hubungan yang semacam ini, terasa sekali tiada kedekatan antar-pribadi. Bila hal ini yang terjadi, proses pembelajaran akan berjalan datardatar saja, serasa hambar, bahkan tidak jarang menjemukan. 


\section{Kajian Teori}

\section{Kompetensi Guru}

Kompetensi adalah suatu hal yang menggambarkan kualifikasi atau kemampuan seseorang (Moh. Uzer Usman, 2009:4). Kompetensi adalah seperangkat tindakan inteligen penuh tanggung jawab yang harus dimiliki seseorang sebagai syarat untuk dianggap mampu melaksanakan tugas-tugas dalam bidang pekerjaan tertentu. Depdiknas merumuskan definisi kompetensi sebagai pengetahuan, keterampilan dan nilai-nilai dasar yang direfleksikan dalam kebiasaan berpikir dan bertindak (Abdul Majid, 2009, p.5-6).

Guru sebagai pendidik atau pun mengajar merupakan faktor penentu kesuksesan setiap usaha pendidikan. Itulah sebabnya setiap perbincangan mengenai pembaharuan kurikulum, pengadaan alat-alat belajar sampai pada kriteria sumber daya manusia yang dihasilkan oleh usaha pendidikan selalu bermuara pada guru. Hal ini menunjukkan betapa signifikasi posisi guru dalam pendidikan (Muhibbin Syah, 2008, p.223).

Guru yang dimaksud dalam pembahasan ini ialah guru profesional yang wajib memiliki komitmen untuk meningkatkan mutu pendidikan. Kegiatan mengajar yang dilakukan guru itu tidak hanya berorientasi pada kecakapankecakapan berdimensi ranah cipta saja tetapi kecakapan yang berdimensi ranah rasa dan karsa. Sebab mengajar pada prinsipnya berarti proses perbuatan seorang guru yang membuat orang lain belajar, dalam arti mengubah seluruh dimensi prilakunya. Mengajar pada hakikatnya sama dengan mendidik.
Karena itu, tidak perlu heran bila seorang guru yang sehari-harinya sebagai pengajar lazim juga disebut pendidik.

Guru profesional adalah orang yang memiliki kemampuan dan keahlian khusus dalam bidang keguruan sehingga ia mampu melakukan tugas dan fungsinya sebagai guru dengan kemampuan maksimal. Atau dengan kata lain, guru profesional adalah orang yang terdidik dan terlatih dengan baik, serta memiliki pengalaman yang kaya di bidangnya (Moh. Uzer Usman, 2009, p.15).

Yang dimaksud dengan terdidik dan terlatih bukan hanya memperoleh pendidikan formal tetapi juga harus menguasai berbagai strategi atau teknik di dalam kegiatan pembelajaran serta menguasai landasan-landasan kependidikan. Kompetensi guru meliputi kompetensi pedagogik, kompetensi kepribadian, kompetensi sosial dan kompetensi profesional yang diperoleh melalui pendidikan profesi (Undang-undang Republik Indonesia, 2012, p.256). Kompetensi guru adalah kemampuan dan kewenangan guru dalam melaksanakan profesinya (Muhibbin Syah, 2008, p.256). Mengingat tugas dan tanggung jawab guru yang begitu kompleksnya, maka seorang guru yang profesional dituntut untuk memiliki beberapa kompetensi khusus yaitu:

\section{Kompetensi Pedagogik}

Kompetensi pedagogik
adalah kemampuan guru dalam
pengelolaan pembelajaran peserta
didik yang sekurang-kurangnya
meliputi:

1) Pemahaman wawasan atau landasan kependidikan. 
2) Pemahaman terhadap peserta didik.

3) Pengembangan kurikulum atau silabus.

4) Perencanaan pembelajaran.

5) Pelaksanaan pembelajaran yang mendidik dan dialogis.

6) Pemanfaatan teknologi pembelajaran.

7) Evaluasi hasil balajar.

8) Pengembangan peserta didik untuk mengaktualisasikan berbagai potensi yang dimilikinya (Undang-undang Republik Indonesia, 2012, p.229).

\section{Kompetensi Kepribadian}

Kompetensi kepribadian adalah kemampuan kepribadian yang sekurang-kurangnya mencakup kepribadian yang:

1) Beriman dan bertakwa.

2) Berakhlak mulia.

3) Arif dan bijaksana.

4) Demokratis.

5) Mantap.

6) Berwibawa.

7) Stabil.

8) Dewasa.

9) Jujur.

10) Sportif.

11) Menjadi teladan bagi peserta didik dan masyarakat.

12) Secara obyektif mengevaluasi kinerja sendiri.

13) Mengembangkan diri secara mandiri dan berkelanjutan (Undang-undang Republik Indonesia, 2012, p.229).

\section{Kompetensi Profesional}

Kompetensi profesional adalah kemampuan guru dalam menguasai pengetahuan bidang ilmu pengetahuan, teknologi, dan/atau seni dan budaya yang diampunya yang sekurang-kurangnya meliputi penguasaan:

1) Materi pembelajaran secara luas dan mendalam sesuai dengan standar isi program satuan pendidikan, mata pelajaran, dan/atau kelompok mata pelajaran yang akan diampu.

2) Konsep dan metode disiplin keilmuan, teknologi atau seni yang relevan, yang secara konseptual menaungi atau koheren dengan program satuan pendidikan, mata pelajaran, dan/atau kelompok mata pelajaran yang akan diampu (Undang-undang Republik Indonesia, 2012, p.230).

\section{Kompetensi Sosial}

Kompetensi sosial adalah kemampuan guru sebagai bagian dari masyarakat yang sekurangkurangnya meliputi kompetensi untuk:

1) Berkomunikasi lisan, tulis, dan/atau isyarat secara santun.

2) Menggunakan teknologi komunikasi dan informasi secara fungsional.

3) Bergaul secara efektif dengan peserta didik, sesama pendidik, tenaga kependidikan, pimpinan satuan pendidikan, orang tua/wali peserta didik.

4) Bergaul secara efektif dengan masyarakat sekitar dengan mengindahkan norma serta sistem nilai yang berlaku.

5) Menerapkan prinsip persaudaraan sejati dan semangat kebersamaan (Undang-undang Republik Indonesia, 2012, p.230). 


\section{Konsepsi Tentang Anak Didik}

$\begin{array}{ccc}\text { Secara } & \text { kodrati anak } \\ \text { memerlukan } & \text { pendidikan atau }\end{array}$ bimbingan dari orang dewasa. Dasar kodrati ini dapat dimengerti dari kebutuhan-kebutuhan dasar yang dimiliki oleh setiap anak yang hidup di dunia ini. Kebutuhan yang harus dipenuhi serta berbagai potensi maupun diposisi untuk dididik, dibimbing dan diarahkan sehingga dapat mengaktualisasikan dirinya dalam kehidupan. Dan membentuk anak didik itu harus sesuai dengan tujuan pengajaran yang diharapkan maka pengajaran harus disesuaikan dengan keadaan dan tingkat kemampuan anak, karakteristik, minat dan lain sebagainya. Itulah sebabnya murid merupakan objek didik dalam pendidikan.

Peserta didik adalah anggota masyarakat yang berusaha mengembangkan potensi diri melalui proses pembelajaran yang tersedia pada jalur, jenjang, dan jenis pendidikan tertentu. Ia adalah pelanggan utama mendapat pelayanan dalam proses pendidikan. Dengan perkataan lain proses pendidikan akan bermakna jika dilakukan oleh, dari, dan untuk peserta didik. Sehingga dari segala potensi yang dimiliki oleh seorang manusia dapat mengembangkan kepribadian diri dan orang lain menuju kesempurnaan (insal kamil). Perkembangan individu (peserta didik) disamping ditentukan oleh aspek dasar (fitrah) juga dipengaruhi oleh faktor ajar (lingkungan).

Pemenuhan kebutuhan peserta didik disamping bertujuaan untuk memberikan materi kegiatan setepat mungkin, juga materi pelajaran yang sudah disesuaikan dengan kebutuhan biasanya menjadi lebih menarik. Dengan demikian akan membantu pelaksanaan proses pembelajaran. Kebutuhan manusia dibedakan menjadi 2 yaitu:

1. Kebutuhan primer, yaitu kebutuhan jasmani seperti makan dan minum.

2. Kebutuhan sekunder, yaitu kebutuhan rohani.

Adapun yang menjadi kebutuhan peserta didik antara lain :

a. Kebutuhan Jasmani

Hal ini berkaitan dengan tuntutan peserta didik yang bersifat jasmaniah. Diantaranya ruang kelas yang memadai dan sarana yang menunjang.

b. Kebutuhan Rohaniah

Hal ini berkaitan dengan pemenuhan kebutuhan peserta didik yang bersifat rohaniah, misalnya siswa merasa puas dengan segala penjelasan dari seorang guru karena penjelasanya memahamkan.

c. Kebutuhan Sosial

Pemenuhan keinginan untuk saling bergaul sesama peserta didik dan pendidik serta orang lain. Dalam hal ini sekolah harus dipandang sebagai lembagai tempat para peserta didik belajar, beradaptasi, bergaul sesama teman yang berbeda jenis kelamin, suku bangsa, agama, status sosial dan kecakapan.

Pendidikan merupakan bimbingan dan pertolongan secara sadar yang diberikan oleh pendidik kepada anak didik sesuai dengan perkembangan jasmaniah dan rohaniah ke arah kedewasaan. Agar pendidikan dapat berhasil dengan sebaik-baiknya haruslah menempuh jalan pendidikan yang sesuai perkembangan anak didik. Anak didik di dalam mencari nilai hidup, 
harus dapat bimbingan sepenuhnya dari pendidik, karena menurut ajaran Islam, saat anak dilahirkan dalam keadaan fitrah/suci sedangkan alam sekitarnya akan memberi corak warna terhadap nilai hidup atas pendidikan agama anak didik (Zuhairini, 2005, p.170).

Dalam kitab maroqil ubudiyah yang menjadi syarah kitab bidayah al-Hidayah, Imam Muhammad Nawawi telah menerangkan tentang etika-etika anak didik terhadap pendidiknya yaitu sebagai berikut:

a). Memulai memberi salam dan minta izin masuk.

b). Sedikit bicara dihadapannya.

c). Tidak berbicara selama tidak ditanya oleh gurunya.

d). Tidak menanyakan sesuatu sebelum minta izin kepada gurunya lebih dulu.

e). Tidak menoleh ke kanan dan kekiri (Muhammad Nawawi, 2010, p.288).

\section{Modal Utama agar Menjadi Guru Favorit bagi Peserta Didiknya}

Modal utama agar menjadi guru favorit bagi peserta didiknya yaitu sebagai berikut:

\section{Dekat dengan Anak Didik}

Modal utama agar menjadi guru favorit atau dicintai oleh peserta didiknya yaitu hubungan yang dekat dengan mereka. Kedekatan dengan anak didik ini bisa dibangun dengan kedekatan secara lahir maupun secara batin. Kedekatan antara guru dan anak didiknya mutlak diperlukan. Hal ini dianggap penting karena proses pembelajaran diyakini tidak akan berjalan dengan lancar dan berhasil secara maksimal tanpa adanya kedekatan antara yang mendidik dengan yang dididik. Dengan adanya kedekatan ini, diharapkan anak didik dapat mengikuti pelajaran yang disampaikan oleh gurunya dengan perasaan yang santai dan pikiran yang tenang. Lain halnya bila guru dan anak didiknya tidak ada jalinan hubungan kedekatan, biasanya proses pembelajaran akan berjalan dengan ketegangan, dengan demikian yang mudah pun bisa menjadi sulit dicerna.

Kedekatan antara guru dan peserta didik diperlukan agar peserta didik dapat belajar dengan baik, terutama ketika menghadapi materi pelajarannya yang sulit dipahami. Maka, peserta didik dapat bertanya tanpa rasa malu kepada gurunya. Tidak adanya peserta didik yang bertanya ketika proses pembelajaran berlangsung bukan selalu berarti semua peserta didik sudah memahami pelajaran yang dimaksud. Bisa jadi mereka enggan bertanya karena tidak adanya kedekatan dengan sang guru. Demikan pula dengan adanya kedekatan seorang guru dapat membantu masalah yang dihadapi oleh peserta didiknya sehingga proses pembelajaran pun tetap berjalan dengan lancar sesuai dengan apa yang diharapkan, yaitu tujuan pendidikan dapat tercapai dengan maksimal.

Kedekatan secara lahir dapat dibangun dengan bentuk perhatian yang diperlihatkan kepada peserta didiknya. Meski diperlihatkan, hal penting yang tidak boleh diabaikan hendaknya dilakukan dengan hati yang ikhlas karena setiap tindakan yang dimulai dari hati yang ikhlas akan 
menimbulkan energi positif yang luar biasa. Bentuk perhatian secara lahir, misalnya menyapa dengan ramah ketika betemu. Di samping seorang guru membangun kedekatan secara lahir, juga tidak kalah pentingnya untuk membangun kedekatan secara batin kepada anak didiknya. Kedekatan ini dapat dilakukan dengan mendokan secara khusus kepada peserta didiknya agar diberi kemudahan dalam belajar dan mencapai kesuksesan. Sungguh, cara ini sangat pening untuk dilakukan oleh seoang guru kepada peserta didiknya. Mendoakan tidak hanya dialakukan hanya sekali saja, tetapi bisa secara istiqamah/berkala, misalnya dilakukan setiap selesai shalat lima waktu dan di tengah malam ketika selesai shalat tahajud.

\section{Membangun Suasana yang Menyenangkan}

$\begin{array}{crr}\text { Orang } & \text { yang } & \text { pandai } \\ \text { membangun } & \text { suasana } & \text { yang }\end{array}$ menyenangkan dalam sebuah hubungan, juga pasti akan disenangi oleh banyak orang. Demikian pula dengan guru hendaknya pandai membawa suasana yang menyenangkan dalam proses pembelajaran, sehingga disenangi oleh peserta didiknya. Penulis sering mengamati bahwa guru favorit adalah seorang guru yang menyenangkan. Siapa saja akan merasa senang bila berada dalam suasana yang menyenangkan, termasuk peserta didik ketika mengikuti proses pembelajaran yang menyenangkan, mereka akan merasa senang.
Seorang guru yang menyenangkan adalah seorang yang mempunyai kepribadian sebagai berikut:

\section{a. Memahami \\ Kebutuhan}

Peserta Didik

Guru yang dicintai oleh peserta didiknya adalah guru yang bisa memahami kebutuhan anak didinya dengan sangat baik. Orang yang demikian biasanya senantiasa mengedepankan dialog yang dianggap penting atau musyawarah terbuka, artinya tidak ada sesuatu yang disembunyikan. Dalam hal ini guru tersebut berusaha untuk mendengarkan apa yng menjadi kebutuhan peserta didiknya (Akhmad Muhaimin Azzet, 2011, p.32).

\section{b. Memberikan Penghargaan}

Seorang guru yang dicintai oleh peserta didiknya adalah yang bisa memberikan penghargaan kepada peserta didiknya. Penghargaan bisa diberikan dengan kata-kata yang baik dan bermanfaat. Misalnya, pada saat seorang peserta didik berhasil mengerjakan pekerjaannya, seorang guru berkomentar, "bagus sekali." Sudah tentu, sang anak didik akan merasa senang dan memuaskan karena mendapat penghargaan dari gurunya.

\section{c. Dapat Mengontrol Emosi dengan Baik}

Menjadi guru tidak selalu menghadapi peserta didik yang baik, sopan, taat, tertib, dan tepat waktu. Ada saja dari peserta didik yang justru sikapnya memancing kemarahan gurunya. Maka, 
guru yang tidak bisa mengontrol emosinya dengan baik, terpancing untuk memarahi peserta didiknya. Berbeda dengan seorang guru yang dapat mengontrol emosinya dengan baik. Jika ada di antara peserta didik yang melakukan perbuatan yang melanggar dari aturan sekolah, ia mencoba untuk memahami mengapa anak tersebut melakukan perbuatan tersebut. Sang guru akan dengan lembut memanggil anak tersebut lantas menanyainya dengan baik.

\section{Bisa Berperan sebagai Orangtua Kedua}

Guru yang bisa

berperan sebgai orangtua kedua bagi anak didiknya ketika berada di sekolah, maka guru tersebut akan dicintai oleh anak didiknya. Seorang guru yang dicintai oleh anak didiknya, menjadi modal untuk dapat dikatakan sebagai guru favorit. Anak didik adalah pribadi yang sesungguhnya masih membutuhkan kasih sayang dan teladan yang baik dalam masa perkembangan jiwanya. Di sinilah mereka sangat membutuhkan dari kedua orang tuanya dalam kehidupan sehari-harinya ketika berada di rumah. Selain di rumah, lingkungan kedua bagi anak didik adalah berada disekolah, disinilah anak didik juga membutuhkan orang yang bisa memberikan kasih sayang dan teladan yang baik, yaitu dari gurunya.

\section{a. Membangun Rasa Kasih}

\section{Sayang}

Rasa kasih sayang yang perlu dibangun adalah rasa kasih sayang sebagaimana orangtua

kepada anaknya. Karena seorang guru bukanlah orangtua kandung bagi nak didiknya, sudah tentu ekspresi dan bentuknya berbeda dengan orangtua kandung mereka dalam memberikan rasa kasih sayang. Rasa ksih sayang yang bersumber dari dalam hati tetaplah perlu dibangun dengan sebaik-baiknya oleh seorang guru yang ingin dicintai oleh anak didiknya, sebagaimana anak mencintai oarng tuanya sendiri.

\section{b. Memberiakan yang Terbaik}

Setiap orangtua ingin memberikan yang terbaik untuk anak-anaknya. Untuk memberikan yang terbaik ini, orangtua bekerja dan berusaha dengan sekuat tenaga. Semua ini dilakukan agar anaknya tumbuh dan berkembang dalam asuhan yang menyenangkan dan dapat meraih keberhasilan dalam dunia pendidikan, baik pendidikan dalam keluarga maupun pendidikan di lembaga sekolah. Disinilah alasan orangtua dicintai dan dihormati denagn setulusnya oleh anakanaknya. Guru sebagai orangtua kedua bagi anak didik ketika berada di lingkungan sekolah, maka ia harus senantiasa membangun kesadarannya untuk bisa memberikan yang terbaik kepada anak didiknya, sebagaimana orangtua memberikan yang terbaik kepada anaknya sendiri.

c. Mendampingi dengan Senang Hati

Salah satu kelebihan orangtua terhadap anak-anaknya adalah 
mendampingi dengan senang hati dalam proses tumbuh dan berkembangnya. Oleh karena itu, anak merasakan nyaman dan damai ketika berada di samping orang tuanya. Meski bukan orangtua kandung, apabila seorang guru dapat membangun kepedulian yang kuat dalam hatinya untuk bisa senantiasa mendampingi anak didiknya dengan senang hati. Maka, seoarng guru tersebut akan disenangi oleh anak didiknya, karena ia mendampingi mereka dengan senang hati.

\section{Menjadi Sahabat dalam Belajar}

Guru yang dicintai oleh anak didiknya adalah yang bisa menjadi sahabat dalam belajar. Guru yang menjadi sahabat ini adalah hal baru dan penting untuk diperhatikan. Peran seorang guru adalah memberikan ilmu kepada anak didiknya. Oleh karena itu, seorang guru akhirnya juga menjadi penguasa tunggal di dalam kelas. Sebagai penguasa tunggal di dalam kelas, seorang guru di zaman dahulu bebas melakukan apa saja, termasuk dalam memberikan hukuman kepada peserta didiknya. Sang anak pun enggan mengadukan perlakuan sang guru tersebut ke orangtuanya. Sebab orangtuanya pun biasanya malah menyalakan anak sendiri yang dituduh tidak patuh pada gurunya (Akhmad Muhaimin Azzet, 2011, p.50).

Di zaman sekarang, sangat mudahnnya akses ilmu pengetahuan, seorang guru yang disenangi peserta didik adalah guru yang dapat menjadi sahabat dalam belajar dan memahami kehidupan yang terus berkembang. Guru yang menempatkan diri sebagai seorang sahabat akan membuat peserta didik merasa dekat dan nyaman. Kedekatan dan rasa nyaman ini sungguh penting kaitannya dengan motivasi dan semangat peserta didik dalam proses pembelajarannya. Peserta didik yang merasakan hubungan dengan gurunya yang tidak kaku, dekat dan penuh persahabatan akan merasakan bahwa belajar di sekolah itu hal yang menyenangkan. Bila peserta didik telah merasakan kesenangan dalam belajar, tentu ia akan bersemangat ketika berada di sekolah. Demikian pula ketika belajar di rumah yang biasanya dilakukan untuk membaca kembali pelajaran di sekolah atau mengerjakan PR dari gurunya di sekolah. Bila hal ini telah terjadi, tujuan proses pembelajaran akan lebih mudah tercapai.

Di zaman sekarang, seorang guru bukanlah satusatunya sumber ilmu pengetahuan, bahkan ada sumber pengetahuan yang lebih mudah di akses. Oleh karena itu, menjadikan peserta didik sebagai sahabat adalah pilihan cerdas bagi seorang guru yang ingin dicintai oleh anak didiknya. Seorang guru yang tampil sebagai sahabat bagi peserta didiknya tentu akan menjadikan pribadinya hangat dan penuh keakraban dengan anak didiknya. Seorang guru yang tampil penuh persahabatan dengan anak didiknya tentu bukan guru yang begitu mudah menjatuhkan hukuman bagi anak didik yang melanggar. Apalagi, 
langsung memberikan hukuman tanpa bertanya sebelumnya kepada anak didiknya mengapa melakukan hal yang tidak baik. Akan tetapi bukan berarti seorang guru tidak boleh memberikan hukuman, jika ada di antara peserta didiknya melakukan pelanggaran, tentu tidak boleh dibiyarkan begitu saja.

\section{Berkepribadian Layak Ditiru}

Seorang guru yang dicintai oleh anak didiknya adalah guru yang mempunyai kepribadian layak ditiru. Inilah kepribadian utama yang harus dimiliki oleh seorang guru. Menurut falsafah jawa, kata guru berasal dari kalimat "bisa digugu (dipercaya) dan ditiru (dicontoh)". Jadi, orang yang menjadi guru adalah seorang yang bisa dipercaya dan ditiru tingkah lakunya oleh anak didiknya. Dua hal sebagaimana tersebut, yaitu bisa dipecaya dan layak ditiru, adalah modal utama bagi siapa saja yang ingin berkepribadian unggul. Bagi seorang guru yang memang pekerjaannya mendidik para peserta didiknya agar pandai di bidang ilmu pengetahuan dan mempunyai budi pekerti yang luhur. sudah tentu, tidak bisa tidak, ia harus bisa dipercaya dan bisa ditiru oleh anak didiknya.

$$
\text { Sebagai guru yang }
$$

bertanggung jawab, tentu tidak ingin apa yang dilakukannya terkait dengan proses pembelajaran mengalami kegagalan. Meskipun kita tidak menutup mata, masih ada juga guru yang mempunyai kepribadian yang tidak bisa dipercaya dan tidak bisa untuk dijadikan contoh atau teladan tingkah lakunya. Meskipun demikian, masih banyak guru yang mencoba untuk terus memperbaiki diri. Bila seorang guru telah mampu menata diri dan menunjukkan bahwa ia layak dipercaya dan bisa dijadikan contoh bagi anak didiknya, ia akan dicintai oleh anak-anak didiknya, bahkan hingga anak didiknya lulus sekolah. Ada tiga modal uatama yang dapat dilakukan oleh seorang guru agar mempunyai kepribadian yang layak ditiru dan dicintai oleh peserta didiknya:

a. Sesuainya kata dan perbuatan

b. Menyadari kedudukannya sebagai seorang guru

c. Terus belajar dan menambah ilmu pengetahuan

\section{Bersikap Kasih Sayang}

Seorang guru yang ingin dicintai oleh anak didiknya harus bisa memberikan kasih sayang kepada mereka. Kasih sayang ini besar pengruhnya dalam rangka mewujudkan keberhasilan peserta didik dalam menguasai standar kompetensi mata pelajarannya ketika proses pembelajaran. Kasih sayang diyakini menjadi sumber mata air kebijaksanan dalam semua sendi kehidupan, termasuk dalam dunia pendidikan, baik pendidikan dalam keluarga maupun pendidikan di sekolah. Sikap seorang guru yang penuh dengan kasih sayang bisa menjadikan semangat tersendiri ketika ia menjalankan tugasnya sebagai guru yang profesional.

Ada tiga modal yang dapat dijadikan bahan pemikiran agar seorang guru dapat 
memberikan kasih sayang secara penuh kepada peserta didiknya:

\section{a. Kasih}

Sayang

Membangkitkan Semangat

Kasih sayang yang diberikan oleh seorang guru kepada peserta didiknya bisa membangkitkan semangat dalam belajar. Sungguh, inilah yang sangat penting dan sangat menentukan dalam keberhasilan proses pembelajaran. Sebab, tanpa adanya semanagat, belajar adalah kegitan yang sangat menjemukan. Bila hal ini terjadi, betapa melelahkannya. Dengan demikian, betapa pentingnya semangat dalam belajar.

b. Tanpa Kasih Sayang = Mendidik Kekerasan

Pendidikan yang di dalamnya tanpa ada kasih sayang sama dengan mendidik kekerasan kepada peserta didik. Sekilas, pernyataan ini terkesan ekstrem. Sebab, tidak ada pendidikan yang secara sengaja mendidik peserta didiknya untuk melakukan tindak kekerasan. Namun, bila hal ini direnungkan sejara jernih, pendidikan yang diselenggarakan tanpa kasih sayang sesungguhnya secara tidak langsung telah mendidik kekerasan kepada peserta didiknya.

c. Belajar dengan Kasih Sayang Berkesan Sepanjang Zaman

Peserta didik yang belajar dengan kasih sayang akan mempunyai kesan yang sangat kuat dalam dirinya. Kesan inilah yang membuat ilmu yang dipelajarinya pun menjadi berguna dan bermanfaat dalam kehidupan di masa depan. Sudah, tentu keasan kuat yang dirasakan oleh setiap manusia ada dua macam, yaitu kesan yang baik dan kesan yang buruk. Namun, kecenderungan manusia adalah segera melupakan kesan yang buruk untuk menuju kehidupan yang baik. Namun, tidak demikian dengan kesan yang baik. Seseorang akan menjaga kesannya yang baik, bahkan jika perlu selalu dikenang (Akhmad Muhaimin Azzet, 2011, p.66).

\section{Sabar dalam Mengajar}

Seorang guru yang dicintai oleh anak didiknya adalah yang sabar dalam menghadapi mereka pada saat proses pembelajaran. Kesabaran seorang guru akan membuat peserta didik merasa nyaman dalam belajar. Kesabaran guru juga membuat peserta didik mempunyai waktu yang cukup untuk lebih memahami pelajaran yang dihadapinya. Inilah kunci yang sangat penting dalam meraih keberhasilan di dunia pendidikan, utamanya di lembaga sekolah. Menurut kamus bahasa Indonesia, sabar mempunyai dua makna, yaitu (1) tahan menghadapi cobaan; (2) tenang, tidak tergesagesa; tidak terburu nafsu.

Berangkat dari pemahaman kata sabar, seorang guru yang ingin beesikap sabar dalam mengajar dapat melakukan dua hal penting sebgai berikut:

\section{a. Tahan dalam Segala Keadaan \\ Menghadapi sikap peserta didik yang tidak sesuai dengan harapan, tidak sedikit guru}


yang menunjukkan sikap tidak sabar. Sikap anak yang tidak sesuai dengan harapan itu bisa jadi berupa perilaku peserta didik yang tidak memperhatikan pelajaran, melanggar kesepakatan, tidak mengerjakan tugas. Sikap tidak sabar yang demikan biasanya ditunjukan dengan sikap jengkel. Inilah sesungguhnya tipe guru yang tidak tahan dalam menghadapi keadaan peserta ddiknya. Namun, bagi seorang guru yang bisa bersabar tentu akan mendapatkan hasil yang menyenangkan.

\section{b. Tenang dan Tidak Tergesa- gesa}

Seorang guru yang mempunyai sifat sabar dalam mendampingi peserta didiknya tentu akan bersikap tenang atau tidak tergesa-gesa. Hal ini penting sekali agar peserta didik dapat mengikuti proses pembelajaran dengan baik. Sebab, daya tangkap setiap peserta didik, pada saat mendengar penjelasan dari sang guru tentu berbeda anatara yang satu dan yang lainnya. Peserta didik yang hanya diterangkan dengan beberapa kalimat saja langsung sudah bisa memahami apa yang telah disampaikan gurunya. Namun, ada juga peserta didik yang membutuhkan waktu agak lama dibandingkan temantemannya. Peserta didik yang lambat dalam memahami pelajaran ini tentu harus diperhatikan pula oleh guru. Pada saat yang seperti ini, seorng guru dibutuhkan kesabarannya untuk menjelaskan dengan kalimatkalimat tambahan atau bahkan pengulangan kepada peserta didiknya (Akhmad Muhaimin Azzet, 2011, p.71).

\section{Tidak Sombong}

Di antara sifat guru yang menyebabkan dicintai oleh anak didiknya adalah seorang guru yang tidak mempunyai sifat sombong. Orang yang sombong suka memandang rendah kepada orang lain dan tinggi hati. Di hadapan peserta didiknya yang masih anak-anak, seorang guru mungkin mempunyai sifat sombong, karena bisa jadi guru tersebut merasa lebih pandai dari pada peserta didiknya. Guru yang sombong, sudah tentu tidak disukai oleh peserta didiknya. Oleh karena itu, seorang guru harus menghindarkan diri sejauh mungkin dari sifat yang sangat buruk ini.

\section{Kesimpulan}

Menjadi guru adalah pekerjaan yang sungguh mulia. Ia bertanggung jawab tidak hanya menjadikan para anak manusia pandai di bidang ilmu pengetahuan, tetapi juga bermoral baik dalam kehidupan ini. Seorang anak manusia yang pada mulanya tidak mengerti apa-apa, di hadapan seorang guru dididik untuk memahami kehidupan secara lebih baik dan mengenal dunia. Di pundaknyalah ada tugas dan tanggung jawab keberlangsungan masa depan generasi yang lebih cerdas dan berperadapan.

Begitu mulia pekerjaan seorang guru sekaligus betapa berat tugas dan tanggung jawab menjadi seorang guru. Inilah mengapa tidak 
semua orang bisa menjadi seorang guru yang berhasil. Hanya orangorang tertentu yang mempunyai rasa cinta terhadap anak-anak atau peserta didik dan berdedikasi tinggi terhadap dunia pendidikan saja yang mampu menjadi seorang guru. Inilah pribadi seorang guru yang berhasil mengajar sekaligus mendidik di hadapan murid-muridnya, sosok seorang guru favorit yang dicintai oleh anak didiknya.

Motivasi dan kecintaan seseorang untuk menjadi guru adalah dasar bagi seorang guru akan sukses dan dicintai oleh murid-muridnya atau tidak. Motivasi dan kecintaan ini harus terpancang sejak awal seseorang menekuni profesi sebagai guru atau bisa pula baru terbangunkan setelah seseorang menjalani profesi ini sekian waktu. Motivasi dan kecintaan ini harus senantiasa dijaga agar seorang tetap bersemangat menghadapi anak didiknya dalam proses pembelajaran. Modal utama agar menjadi guru favorit bagi peserta didiknya yaitu sebagai berikut:

1. Dekat dengan anak didik

2. Membangun suasana yang menyenangkan

3. Bisa berperan sebagai orangtua kedua

4. Menjadi sahabat dalam belajar

5. Berkepribadian layak ditiru

6. Bersikap kasih sayang

7. Sabar dalam mengajar

8. Tidak sombong.

\section{Daftar Rujukan}

Azzet, Akhmad Muhaimin (2011). Menjadi Guru Favorit. Cetakan I. Jogjakarta: ArRuzz Media.

Ismail (2009). Strategi Pembelajaran Agama Islam Berbasis PAIKEM. Cetakan IV. Semarang: Rasail Media Group.

Majid, Abdul (2009). Perencanaan Pembelajaran. Cetakan VI. Bandung: PT Remaja Rosdakarya.

Nawawi, Muhammad (2010). Maroqil Ubudiyah, diterjemahkan oleh Zaid Husein, Terjemah Maroqil Ubudiyah. Cetakan I. Surabaya: Mutiara Ilmu.

Syah, Muhibbin (2008). Psikologi Pendidikan dengan

Pendekatan Baru. Cetakan XIIII. Bandung: PT Remaja Rosdakarya.

Tafsir, Ahmad (2014). Ilmu Pendidikan dalam Perspektif Islam. Cetakan XI. Bandung: PT Remaja Rosdakarya.

Undang-undang Republik Indonesia No.14 tahun 2005 tentang guru dan dosen (2012) Undang-Undang Tentang Guru dan Dosen. Bandung: Citra Umbara.

Usman, Moh. Uzer (2009). Menjadi Guru Profesional. Cetakan XX111. Bandung: PT Remaja Rosdakarya.

Zuhairini (2005). Filsafat Pendidikan Islam. Cetakan II. Jakarta: Bumi Aksara. 
Yazidul Busthomi

106 Annaba : Jurnal Pendidikan Islam 